\title{
Direct Visualization of Formylpeptide Receptor Binding on Rounded and Polarized Human Neutrophils: Cellular and Receptor Heterogeneity
}

\begin{abstract}
Robert J. Walter and Wayne A. Marasco
Department of Anatomy, University of Illinois at Chicago, Chicago (R.J.W.) and Departments of Pathology and Internal Medicine, University of Michigan Medical School, Ann Arbor (W.A.M.)

We have used light microscope autoradiography to visualize binding of the formylhexapeptide, N-formyl-norleucyl-leucyl-phenylalanyl-norleucyl-( ${ }^{125}$ ) tyrosyl-lysine to rounded and spontaneously polarized human polymorphonuclear leukocytes. These cells possess receptors known to bind with high specificity and great avidity to the chemotactic formyipeptides. Cells adherent to glass slides were exposed to $\left({ }^{125} \mathrm{~J}\right)$-hexapeptide at $4^{\circ} \mathrm{C}$, fixed, and autoradiographed. Hexapeptide binding was studied over the biologically active range of peptide concentrations varying from $0.63 \mathrm{nM}$ to $10 \mathrm{nM}$ and autoradiographic silver grains counted on 200 rounded or 50 polarized cells at each concentration. Examination of histograms plotted from these data revealed for rounded cells: 1) two major peaks at each concentration indicating the existence of two neutrophil subpopulations, the predominant subpopulation binding one-half as much formylpeptide (peak l) as the other (peak II); 2) progressively increasing proportions of cells in peak II as the free hexapeptide concentration increased. Accordingly, at $0.63 \mathrm{nM}$ hexapeptide, peak II comprised only $8 \%$ of the total cell number, whereas at $10 \mathrm{nM}$, this peak represented $35 \%$ of the total cells. This suggested that different types of receptors may exist in the two cell subpopulations (high/low affinity or high/low negative cooperativity) and that these receptor types were expressed differentially on these subpopulations. Thus, cellular heterogeneity within the neutrophil population and receptor heterogeneity among hexapeptide receptors on an individual cell were both observed here. Each of these may significantly affect neutrophil functional responses to the chemotactic formylpeptides and may explain, at least in part, the curvilinearity in the Scatchard plots of formylpeptide receptor binding that has recently been reported.

At higher concentrations of peptide ( $\geqslant 5 \mathrm{nM}$ ), spontaneously polarized PMN bound hexapeptide more or less uniformly over the entire cell surface. However, at lower concentrations, hexapeptide binding was markedly shifted toward the cell anterior. As a group, polarized PMN bound similar total quantities of hexapeptide, as did rounded PMN at each peptide concentration tested. Receptors displaying high- and low-affinity characteristics were, however, distributed asymmetrically over the cell surface, with the high-affinity type receptors predominantly on the anterior one-half of the cell. Such an asymmetric distribution may serve to initiate or perpetuate cell locomotion.
\end{abstract}

Key words: chemotaxis, human leukocytes, formylpeptide, receptors, heterogeneity, binding affinity

\section{INTRODUCTION}

Polymorphonuclear leukocytes (PMN) are highly phagocytic components of the immune system that respond chemokinetically and chemotactically to soluble bacterial factors $[4,27,41]$. PMN must continually monitor and respond to such soluble chemotactic stimuli in order to detect concentration gradients of soluble factors and also to initiate and to perpetuate stimulated and directional locomotion. These activities are mediated by cell surface receptors that bind certain specific classes of chemotactic molecules [34,42]. Among these factors are

(C) 1987 Alan R. Liss, Inc. the naturally occurring formylmethionylpeptides $[2,55]$, a group of molecules now known to be the $\mathrm{NH}_{2}$-terminal post-translational clip products of nascent bacterial proteins as well as bacterial signal peptides. Purified synthetic analogues of these naturally occurring bacterial substances are also potent leukocyte chemoattractants $[21,24,41,42]$.

Received August 30, 1986; accepted November 12, 1986.

Reprint requests: Robert J. Walter, Department of Anatomy M/C 512, University of Illinois at Chicago, P.O. Box 6998, Chicago, IL 60680. 
In the past, suspensions of PMN isolated from any given individual were considered to be rather homogeneous with respect to chemoattractant binding. However, this notion must be reassessed in light of recent evidence that PMN populations are quite heterogeneous $[6,7$, $8,10,35,37]$. Subpopulations of leukocytes have been reported, each of which expresses its own characteristic number of receptors for formylpeptide chemoattractants. In addition, recent findings suggest that PMN receptors for formylpeptides and those for leukotriene B4 may also express more than one binding affinity for ligand $[9,17,19,36,40]$. Such heterogeneity within the PMN population and among the formylpeptide receptors themselves has been shown indirectly, using receptor-binding kinetics or flow cytometry. Using these techniques, it has only recently been possible to determine that cell heterogeneity and formylpeptide receptor heterogeneity coexist within the same population of cells [23]. We have demonstrated both types of heterogeneity in populations of human PMN binding the formylpeptide chemoattractant, formyl-norleucyl-leucyl-phenylalanyl-norleucyl-( $\left.{ }^{125} \mathrm{I}\right)$ tyrosyl-lysine. This heterogeneity has been visualized directly using light microscope autoradiographic methods. Our results indicate that both cell and receptor binding heterogeneity occur simultaneously in populations of human PMN.

Several types of membrane receptors exhibit inherent anteroposterior asymmetric distributions on the cell surface of motile leukocytes $[38,47,50-53]$. Such asymmetries may facilitate motility-related activities such as phagocytosis, receptor-mediated endocytosis, and chemotaxis in these cells. Transcellular asymmetries of formylpeptide receptors across the cell surface of rounded or polarized PMN might play a significant role in modulating the cell's initial or continued response to chemotactic stimuli. We have examined the occurrence and distribution of hexapeptide receptors on the surface of spontaneously polarized PMN using a range of hexapeptide binding concentrations. At high binding concentrations $(\geqslant 5 \mathrm{nM})$, hexapeptide was found to bind more or less uniformly over the entire cell surface. However, at lower concentrations $(\leqslant 2.5 \mathrm{nM})$, hexapeptide bound asymmetrically, predominantly over the anterior half of polarized PMN.

\section{MATERIALS AND METHODS Isolation of Human Peripheral PMN}

Whole peripheral blood drawn from healthy volunteers into tubes containing EDTA was allowed to undergo gravity sedimentation for $45 \mathrm{~min}$ at room temperature. The leukocyte-rich plasma was drawn off and then diluted $1: 1$ with buffer containing $140 \mathrm{mM} \mathrm{NaCl}, 10 \mathrm{mM}$ $\mathrm{KCl}, 10 \mathrm{mM}$ HEPES, $5 \mathrm{mM}$ glucose, and $2 \mathrm{mg} / \mathrm{ml}$ bovine serum albumin, pH 7.4 (HBS). This suspension was gently layered onto $1 \mathrm{ml}$ of lymphocyte separation medium (Bionetics, Kensington, MD), and the discontinuous gradient centrifuged at $500 \times \mathrm{g}$ for $5 \mathrm{~min}$ in a clinical centrifuge. The supernatant was aspirated, the cell pellet resuspended in HBS containing 2 mM EDTA, and this suspension centrifuged momentarily in an Eppendorf centrifuge. Erythrocytes in the cell pellet were lysed by hypotonic shock and the PMN rinsed three times in HBS containing EDTA. Cells were then stored at $4^{\circ} \mathrm{C}$ until use. Cell preparations contained more than $95 \%$ polymorphonuclear leukocytes, with the remaining cells being predominantly eosinophils $[50,51]$.

\section{Exposure to lodinated Hexapeptide}

PMN suspended in $25 \mu \mathrm{l} \mathrm{HBS}$ containing $1 \mathrm{mM} \mathrm{MgSO}_{4}$ and $0.2 \mathrm{mM} \mathrm{CaCl}_{2}$ were placed onto acid-cleaned glass microscope slides in a humidified chamber for $5 \mathrm{~min}$ at $37^{\circ} \mathrm{C}$. Subsequently, $25 \mu \mathrm{l}$ of $\left({ }^{125} \mathrm{I}\right)$-labeled hexapeptide $(2,000 \mathrm{Ci} / \mathrm{mmole})$ in the same buffer was added to each slide and the slides with adherent cells incubated further at $4^{\circ} \mathrm{C}$ for $15 \mathrm{~min}$. $\mathrm{N}$-formyl-norleucyl-leucyl-phenylalanyl-norleucyl-tyrosyl-lysine (Peninsula Laboratories, Belmont, CA) was iodinated at the tyrosine position using carrier-free $\mathrm{I}^{125}$ by the chloramine-T method as described previously [13-15,22]. The binding characteristics (i.e., saturation curves, reversibility of binding, equilibrium conditions) of this probe have been reported previously [28]. The final concentrations of $\left({ }^{125} \mathrm{I}\right)$-hexapeptide used were $10 \mathrm{nM}, 5 \mathrm{nM}, 2.5 \mathrm{nM}, 1.25 \mathrm{nM}$, and $0.63 \mathrm{nM}$. In addition, control experiments for nonspecific binding were performed in which unlabeled hexapeptide (1,000-fold excess) was added simultaneously with iodinated hexapeptide. Upon completion of this incubation, all slides and adherent PMN were rinsed quickly in two changes of HBS and once in HBS lacking bovine serum albumin. Slides were then submerged in cold fixative solution containing $1.5 \%$ glutaraldehyde, $1.0 \%$ paraformaldehyde, and $0.1 \mathrm{M}$ cacodylate, $\mathrm{pH}$ 7.2.

\section{Autoradiography and Sampling Procedures}

Cells were fixed overnight, rinsed in $0.1 \mathrm{M}$ cacodylate buffer, in Dulbecco's modified Eagle's medium, in cacodylate buffer again, and then dehydrated in graded ethanols to $80 \%$ ethanol. Cells were then rehydrated, and slides were dipped in Kodak NTB-2 emulsion (diluted 1:5 with distilled water), air dried, and stored for 3 days at $4^{\circ} \mathrm{C}$ in the dark. Exposed autoradiographs were developed using Kodak D-19, fixed, stained in eosin and cresyl violet, and coverglasses affixed using Permount [52].Localization of radioactive sources by this method was generally good, with the great majority of exposed silver grains lying very close to the cell surface (within 1 $\mu \mathrm{m})[5,32]$. Grains overlying the cell contours seen by phase contrast were counted, whereas grains lying more than $1 \mu \mathrm{m}$ outside this profile were considered to be background and not cell associated. 
Cells were examined and photographed using a Nikon Optiphot microscope equipped with an Olympus OM-2n camera. Phase-contrast optics were used to determine cell morphology and dark-field optics to visualize and count silver grains associated with the cells. For receptor-binding studies on rounded PMN, grains associated with 200 cells were counted for each experimental group. Three experiments were performed and duplicate slides were run for each hexapeptide concentration.

Polarized cells were identified using phase contrast optics and their overall length measured using an eyepiece reticle. This length was halved and the micrometer line corresponding to this midpoint used to distinguish the anterior or front half of the cell from the posterior or rear half of the cell. This midpoint was usually found to lie at the posterior boundary of the nucleus. Grains over each half of the PMN were counted and the ratio of grains on the front:rear of the cells calculated. Fifty polarized cells in each group were assessed, three separate experiments were performed, and duplicate slides were run for each hexapeptide concentration.

Our method for dividing PMN into anterior and posterior halves was based upon the spatial sensing hypothesis for chemotaxis [1,27,34]. According to this model, cells sense concentration gradients of chemoattractants by differential occupancy of receptors across the cell surface. Thus, the distance from the leading edge to the trailing uropod tip may well affect the cell's capacity to sense a concentration gradient or to respond appropriately to a chemotactic factor [31]. Since the anteroposterior distance may be a physiologically significant parameter, our division of PMN simply into anterior and posterior halves should provide some measure of this parameter.

This method does not compensate for possible differences in the amount of plasma membrane, in organelle distributions within the PMN, or possible differences in adhesion between the front and rear of these cells. Although such factors are undoubtedly important in initiating and perpetuating chemokinesis and chemotaxis $[42,43,45,46]$, their exact significance in these activities is unproven. Nevertheless, this method was expeditious and provided useful information without exceeding the resolution of the autoradiographic technique $[5,32,52]$.

\section{Statistical Analyses}

For rounded PMN, frequency distribution histograms were generated from these grain counts (using ABSTAT, Anderson-Bell's statistics package), with the abscissa representing the amount of hexapeptide bound to individual cells within the leukocyte population and the ordinate representing the number of frequency of cells in the population exhibiting a given level of hexapeptide bind- ing. These histograms were then analyzed using PEAKFIT (EMF Software, Knoxville, TN). This program fits data to one or multiple Gaussian peaks by a non-linear least-squares method using the Simplex algorithm. The number of population means, their values, and variances were first approximated by eye from the frequency distribution to establish a starting point for the fit. The program then defined the normal curve(s) that most closely fit the experimental data. Usually 100-300 curve fitting operations and refinements were required for the program to obtain the closest fit. Goodness of fit for single or multiple peaks, mean values, standard deviations, and peak areas were calculated; $F$ tests comparing the fit for distributions having one or two peaks were performed using PEAKFIT $[25,26]$.

For polarized cells, grains were counted on the front and rear halves of 50 cells at each hexapeptide concentration. These values were then compared using paired $t$ tests. The ratio of grains on the front:rear halves of cells exposed to $10 \mathrm{nM}$ iodinated hexapeptide was calculated. This ratio was then compared to similar ratios calculated for polarized cells exposed to other concentrations of hexapeptide using the Mann-Whitney U-test. In addition, the total number of grains counted on polarized cells at each concentration of iodinated hexapeptide was compared to that obtained for rounded cells at these same concentrations using chi-square.

\section{RESULTS}

\section{Receptor Saturation Experiments: Rounded Cells}

Human PMN exposed to $\left(\mathrm{I}^{125}\right)$-labeled hexapeptide bound substantial amounts of peptide to their cell surface (Figs. 1, 2). The silver grain counts seen after 3 days exposure ranged from an average of 7.8 grains/cell at $0.63 \mathrm{nM}$ iodinated hexapeptide to 41.2 grains/cell at 10 $\mathrm{nM}$ iodinated hexapeptide. Nonspecific binding of hexapeptide plus emulsion background silver grains never exceeded an average of 0.6 grains/cell (i.e., $2-8 \%$ of total). Figure 3 shows a saturation curve of the data obtained from these experiments. As can be seen, binding approached saturation at high hexapeptide concentrations such that an overall 16-fold increase in hexapeptide concentration was accompanied by a 5-fold increase in hexapeptide binding to PMN. As expected, the rate of increase in binding was gradually reduced at higher hexapeptide concentrations. In individual experiments, a distinct tendency for large variances in the cell population with regard to the number of grains per cell was also noted. However, between experiments the variance was considerably smaller. As a result, we further examined individual cells within the population to determine whether the amount of hexapeptide binding per cell was described by a normal curve. 

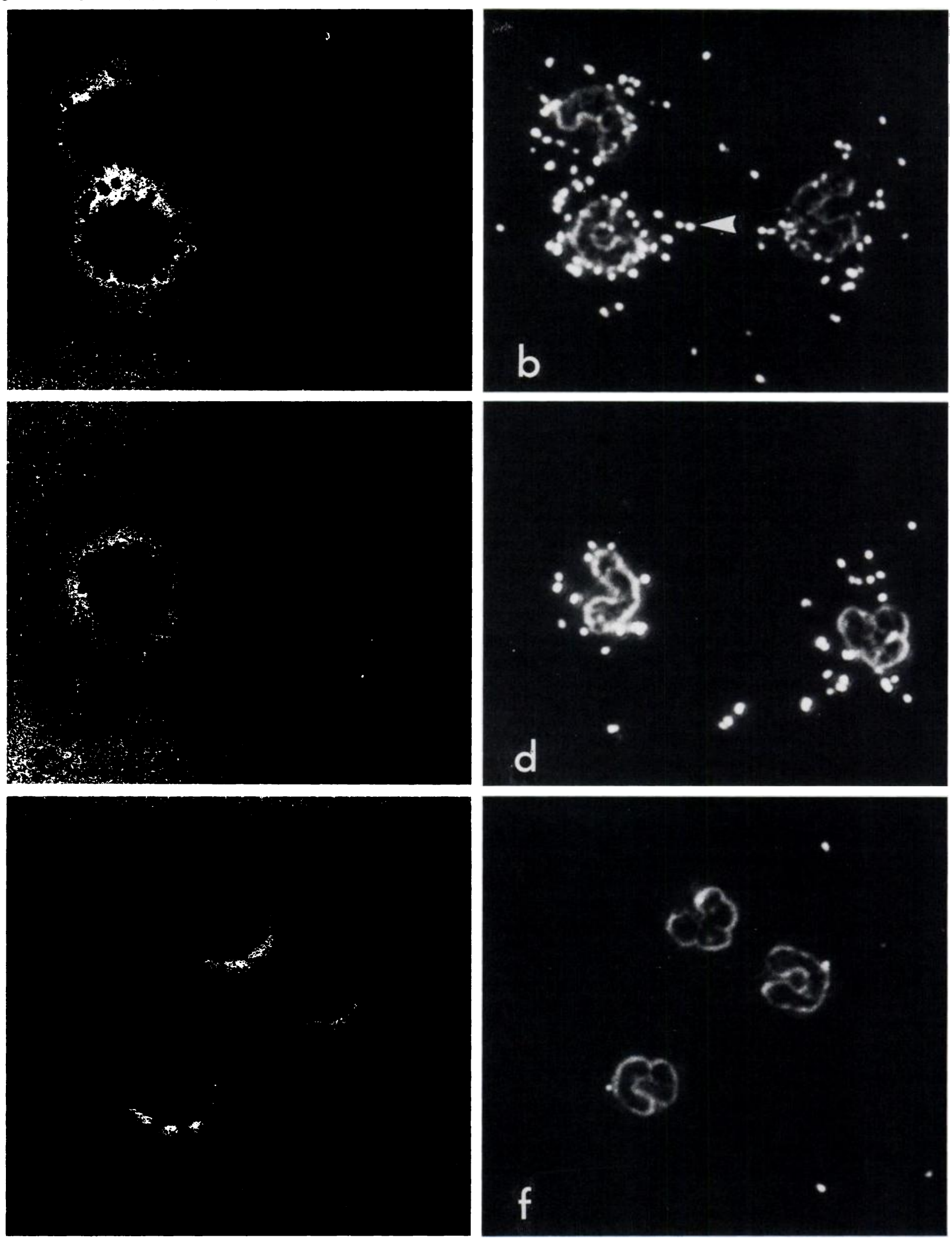

Fig. 1. Light micrographs of rounded, nonmotile human PMN exposed to $10 \mathrm{nM}(\mathrm{a}, \mathrm{b})$ or $5 \mathrm{nM}$ (c, d) $\left({ }^{125} \mathrm{I}\right)$-hexapeptide for 15 $\mathrm{min}$ at $4^{\circ} \mathrm{C}$. Cells exposed simultaneously to $10 \mathrm{nM}\left({ }^{125} \mathrm{I}\right)$-hexapeptide and $10 \mu \mathrm{M}$ unlabeled hexapeptide are shown in $e$ and $\mathrm{f}$. Cell monolayers were viewed using phase-contrast optics (left column) or dark-field optics (right column) to accentuate the sllver grains. Controls for nonspecific binding and emulsion

background $(e, f)$ are virtually free of silver grains. On the other hand, many grains are seen overlying cells exposed to $10 \mathrm{nM}$ labeled formylpeptide (a, b), and somewhat fower over cells exposed to $5 \mathrm{nM}$ hexapeptide (c, d). A cell exhibiting a particularly large number of grains is seen in the top panel $(a, b)$ (arrow). Such cells are characteristic of those found in peak II of Figure 4. Magnification bar $=10 \mu \mathrm{m}$. 

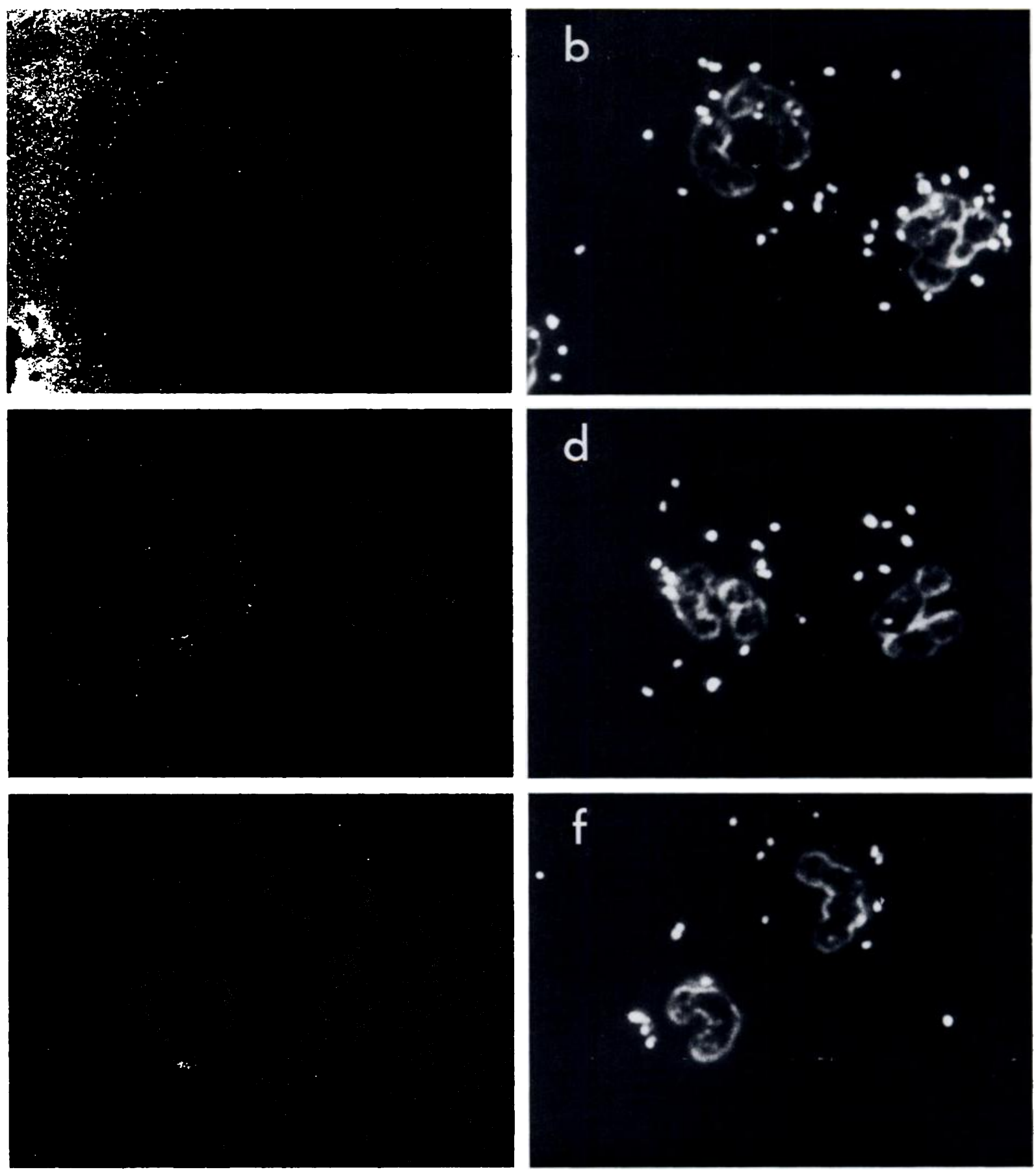

Fig. 2. Phase contrast (loft) and dark-field (right) micrographs of rounded PMN exposed to $2.5 \mathrm{nM}(\mathrm{a}, \mathrm{b}), 1.25 \mathrm{nM}(\mathrm{c}, \mathrm{d})$, or $0.63 \mathrm{nM}\left({ }^{125} \mathrm{l}\right)$-hexapeptide $(e, \mathrm{f})$. As the concentration of labeled hexapeptide was decreased, the number of grains over the PMN also declined. Magnification bar $=10 \mu \mathrm{m}$.

\section{Hexapeptide Binding to PMN in the Sample} Population

The silver grains associated with $200 \mathrm{PMN}$ were counted for cells exposed to $0.63,1.25,2.5,5.0$, or 10 $\mathrm{nM}\left(\mathrm{I}^{125}\right)$-hexapeptide. Histograms generated from this data are shown in Figure 4 and summarized in Table 1. For cells at each binding concentration of iodinated hex- apeptide, bimodal distributions of hexapeptide binding clearly emerged. The PEAKFIT program showed that the fit for two peaks was significantly better in each case than the fit for a single peak (see Table 1). The relative numbers of cells in each subpopulation (peaks I and II) varied, depending on the initial binding concentration of hexapeptide, but the bimodal character of the curves was still evident. 


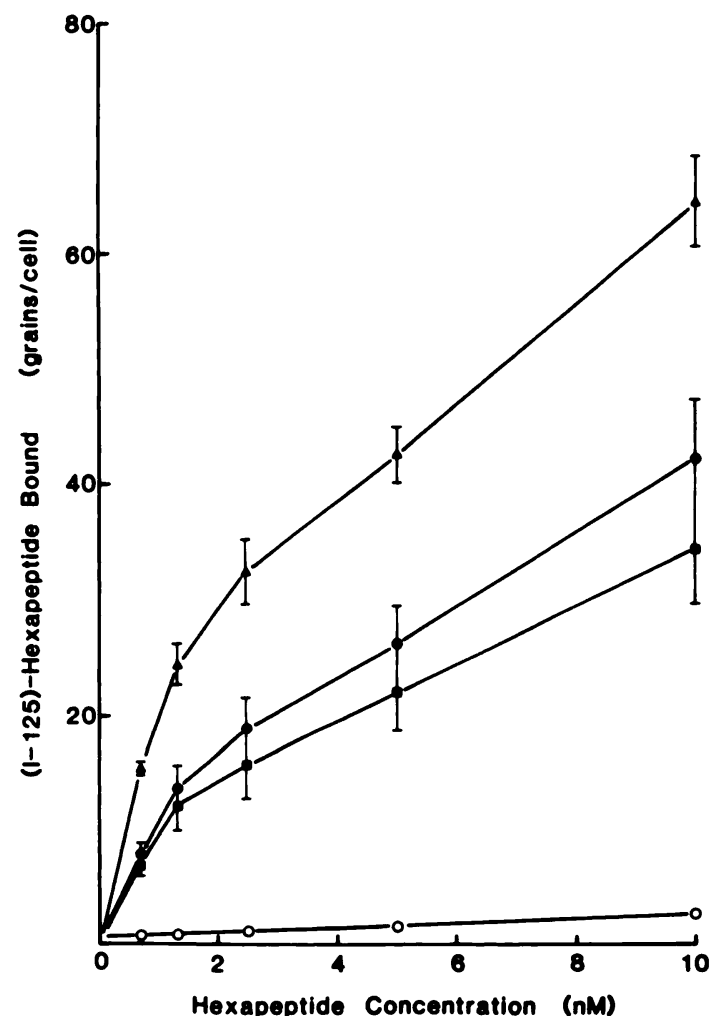

Fig. 3. Saturation plot for hexapeptide binding to human PMN generated from light microscope autoradiograph grain counts. The cells were exposed to $\left({ }^{125} \mathrm{I}\right.$-hexapeptide for $15 \mathrm{~min}$ at $4^{\circ} \mathrm{C}$, fixed, autoradlographed, and the grains overlying 200 cells counted. The mean numbers of graina/cell were calculated for subpopulations seen at each concentration of hexapeptide (mean \pm SD). The means for the subpopulation binding larger amounts of hexapeptide (peak II, $\Delta$ ), means for the subpopulation binding leseer amounts of hexapeptide (peak I, $\square$ ), and overall population means $(O)$ are shown. Hoxapeptide binding was also assessed in the presence of 1,000-fold excess unlabeled hexapeptide (O).
It seems evident from these data that there are two distinct subpopulations of PMN within a suspension or monolayer of cells. The ratio of the mean grain counts per cell for the two PMN subpopulations seen is more or less constant at about 0.50 . One of these subpopulations seems to bind approximately twice as much hexapeptide as does the other. These two subpopulations seemed to be distinct and separate in regard to the amount of hexapeptide bound, but otherwise they exhibited very similar saturation characteristics (see Fig. 3). Seligmann et al [35] have also demonstrated the occurrence of cellular heterogeneity using flow cytometry. In their study, about $40 \%$ of the PMN population displayed membrane depolarization in the presence of formyl-methionyl-leucylphenylalanyl-lysine, and this subpopulation showed about $25 \%$ more formylpeptide binding than the nonresponding subpopulation. At $10 \mathrm{nM}$ hexapeptide, we saw $35 \%$ of the PMN population binding about $100 \%$ more hexapeptide. Differences in experimental conditions (notably, temperature and length of time allowed for binding) may account for this discrepancy.

Furthermore, the proportion of cells in each peak varied depending on the initial concentration of hexapeptide present during binding. PMN from the subpopulation having more binding per cell (peak II) comprised $8 \%$ of the total population at $0.63 \mathrm{nM}\left({ }^{125} \mathrm{I}\right)$-hexapeptide, $15 \%$ at $1.25 \mathrm{nM}, 18 \%$ at $2.5 \mathrm{nM}, 21 \%$ at $5 \mathrm{nM}$, and $35 \%$ at $10 \mathrm{nM}$. This progression of increasing cell frequencies may indicate that the cells in peak II are expressing a different type of binding site for hexapeptide, which is only expressed fully as the hexapeptide concentration is increased toward saturation. One possibility in this regard is that receptors having different affinities or a single receptor having high- and low-affinity states might exist (see Fig. 5). The aforementioned similarities in the saturation characteristics of both subpopulations might

TABLE 1. Autoradiographic Grain Counts for Neutrophils Exposed to Varying Concentrations of ( ${ }^{125}$ I)Hexapeptide

\begin{tabular}{lccccc}
\hline \multirow{2}{*}{$\begin{array}{l}{ }^{125} \text { I)-hexapeptide } \\
\text { concentration (nM) }\end{array}$} & \multicolumn{2}{c}{ Grains/cell (mean \pm SEM) } & & Ratio of means \\
(peak I/peak II) & $P^{\mathrm{a}}$ \\
\hline 10 & $34.5 \pm 5.5(65)^{\mathrm{b}}$ & $64.1 \pm 3.7(35)$ & & 0.54 & $<.005$ \\
5 & $22.0 \pm 3.4(79)$ & $42.7 \pm 2.5(21)$ & & 0.52 & $<.0001$ \\
2.5 & $15.9 \pm 2.9(82)$ & $32.6 \pm 2.8(18)$ & & 0.49 & $<.05$ \\
1.25 & $12.3 \pm 2.1(85)$ & $25.6 \pm 1.8(15)$ & & 0.48 & $<.03$ \\
0.63 & $7.2 \pm 1.2(92)$ & $15.3 \pm 0.5(8)$ & & 0.47 & $<.04$ \\
\hline
\end{tabular}

${ }^{a} \mathrm{Grains}$ associated with 200 cells were counted at various concentrations of $\left({ }^{125} \mathrm{I}\right)$-hexapeptide. Using these grain counts, histograms were generated using ABSTAT, and these frequency distributions were analyzed using PEAKFIT computer analysis. Two subpopulations of PMN were demonstrated at each concentration of labeled hexapeptide tested. For details of these procedures see Materials and Methods section.

b The percentage of the total cells in each subpopulation.

'Comparison of F ratios (from PEAKFIT) for experimental population distribution with theoretical normal distribution having either one or two peaks. $\mathbf{P}=$ probability that simpler model (one-peak model) is preferred. 

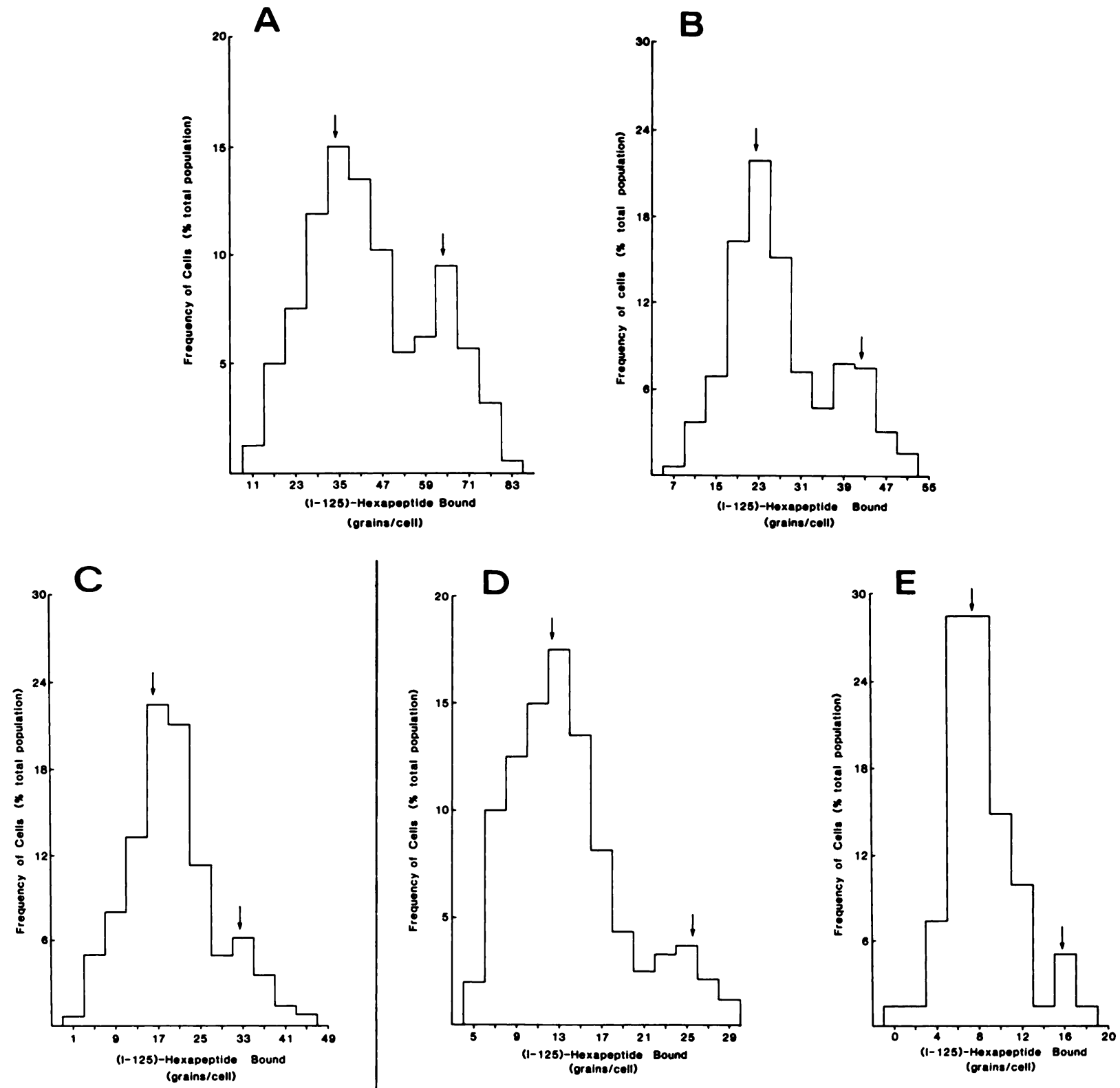

Fig. 4. Histograms showing the frequency of cells and the amount of hexapeptide bound by cells (grains/cell) exposed to different concentrations of $\left({ }^{125} \mid\right)$-hexapeptide. Two hundred cells were counted, and they appear to fall into two subpopulations. At $10 \mathrm{nM}$ hexapeptide (a), one subpopulation has a mean of 35.5 (peak I) and the other a mean of 64.1 (peak II) grains/cell (arrows). At $5 \mathrm{nM}$ ( ${ }^{125} \mathrm{l}$ )-hexapeptide (b), a prominent peak or subpopulation having a mean of 22.0 and a smaller subpopulation having a mean of $\mathbf{4 2 . 7}$ grains/cell are evident (arrows). At $2.5 \mathrm{nM}\left({ }^{125} \mathrm{l}\right)$-hexapeptide (c), the predominant subpopulation of cells shows a mean grain count of 15.9 , while the

smaller subpopulation displays a mean grain count of 32.6 grains/cell (arrows). For cells exposed to $1.25 \mathrm{nM}\left({ }^{125} \mid\right.$ )-hexapeptide during binding (d), approximately $85 \%$ of the population is found in a subpopulation having a mean grain count of 12.3, while the remaining cells is in a subpopulation having a mean grain count of 25.6 grains/cell (arrows). For cells exposed to $0.63 \mathrm{nM}\left({ }^{125}\right)$-hexapeptide (e), only $8 \%$ of the population remained in the second peak with a mean grain count of 15.3 grains/cell. Ninety-two percent of the PMN were found in the other subpopulation and the mean number of grains associated with these cells dropped to 7.2 grains/cell (arrows).

tend to favor this latter interpretation. On the other hand, Marasco et al [23] have demonstrated negative cooperativity among the formylpeptide receptors of rat [neutrophil plasma membranes and on whole rat neutrophils Marasco, W.A., Feltner, D.E., and Ward, P.A., unpublished results]. Heterogeneity in the expression of such destabilizing receptor interactions might also account for

the progressively decreasing cell frequencies seen here. Accordingly, it might be argued that cells in peak II express little receptor negative cooperativity relative to cells found in peak $\mathrm{I}$.

The morphological appearance of PMN from both subpopulations (peak I and peak II) was also compared (see Fig. 1). There was some variation in the relative degree 
RECEPTOR AFFINITY

A)Two Distinct Receptors
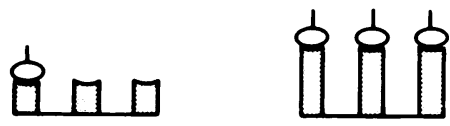

B) Altered Receptor Conformation

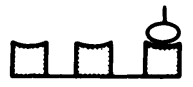

NEGATIVE COOPERATIVITY

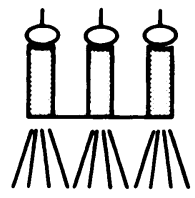

C) Inherent Receptor Clustering
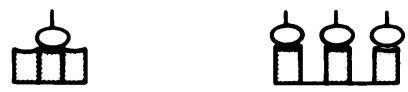

D)Altered Membrane Conformation
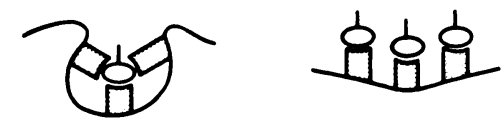

High-Affinity Hexapeptide Receptor (or low negative cooperativity)

$\square$ Low-Affinity Hexapeptide Receptor (or high negative cooperativity)

\& Hexapeptide

Fig. 5. Schematic representation of possible mechanisms for receptor heterogeneity in human PMN. When binding occurs at a given hexapeptide concentration (e.g., $10 \mathrm{nM}$ ), some receptors may bind peptide avidly (right column) while others bind it poorly (left column). Such heterogeneity is generally attributed to the occurrence of receptors having either different affinities $(a, b)$ or different degrees of destabilizing interactions, that is, negative cooperativity (d). Differences in receptor affinities may be generated as a result of either the existence of two distinctly different receptors each with different affinities for hexapeptide (a) or perturbations of a single receptor type by some outside influence (b) altering its hexapeptide binding capacity. On the other hand, destabilizing receptor interactions may affect hexapeptide binding even to a single class of hexapeptide receptors. Such receptor-receptor interactions might become significant when receptors lie in close proximity to one another. These destabilizing conditions might occur as the result of inherent receptor clustering (c) or plicated, Irregular membrane conformations (d) existing locally on the cell surface.

of cell flattening and in the nuclear stain intensity throughout the PMN population, but these differences did not seem to correlate with differences in the hexapeptide binding. No differences in the sizes of the cells or in the nuclear morphology between the two groups were observed. Thus, cells in each of the two subpopulations showed no morphologic differences correlating with the observed differences in hexapeptide binding (a cell from peak II is seen in Fig. 1 at arrow).

\section{Hexapeptide Distribution on Polarized PMN}

PMN exposed to $\left({ }^{125} \mathrm{I}\right)$-hexapeptide at $4^{\circ} \mathrm{C}$ for $15 \mathrm{~min}$ were studied to determine the distribution of silver grains on spontaneously polarized or motile cells. Many silver grains were seen on cells exposed to $10 \mathrm{nM}$ hexapeptide, and the grains seemed to be distributed somewhat uniformly on the cell surface of polarized PMN (Fig. 6a, b). Fewer grains were seen on cells exposed to $5 \mathrm{nM}$ hexapeptide, but the grains were still distributed somewhat uniformly over the entire cell surface (Fig. 6c, d). However, as the concentration of iodinated hexapeptide was decreased further, the distributiopn of grains shifted. Cells exposed to $2.5 \mathrm{nM}\left({ }^{125} \mathrm{I}\right)$-hexapeptide displayed grains predominantly over the anterior half of the cell (Fig. 7a, b). At lower concentrations of hexapeptide (Fig. 7c-f) this same phenomenon became more apparent. Increasingly, receptors occurred on the front half of each cell, while fewer appeared on the rear half. The numbers of nonspecific and background grains were always very low (Figure $7 g, h$ ).

Grain counts performed on polarized PMN are seen in Table 2. Polarized cells exposed to $0.63,1.25,2.5,5$, or $10 \mathrm{nM}\left({ }^{125}\right)$-hexapeptide were studied, and grains on the front and rear halves of each cell were counted as described in the Methods section. Fifty cells were studied in each group for each experiment, and three experiments were performed. At 5 and $10 \mathrm{nM}$ concentrations, PMN exhibited a slight anterior tendency in their distribution of hexapeptide binding sites. As a result, the ratio of grains counted on the front:rear of these cells was slightly elevated (1.41 for cells at $10 \mathrm{nM}$ and 1.37 for cells at 5 $\mathrm{nM}$ ). At lower concentrations of hexapeptide, however, a much greater anteriorward shift in the distribution of grains on polarized PMN occurred. Cells exposed to $0.63,1,25$, or $2.5 \mathrm{nM}$ hexapeptide bound less peptide, of course, but the ratio of grains seen on the front:rear of these cells was dramatically increased (2.86 at 2.5 $\mathrm{nM}, 3.33$ at $1.25 \mathrm{nM}$, and 4.00 at $0.63 \mathrm{nM}$ ). The ratios of grains counted front:rear for cells exposed to $2.5 \mathrm{nM}$ or less hexapeptide were significantly different $(P<$ .001 , Mann-Whitney U-test) from those obtained for cells exposed to 5 or $10 \mathrm{nM}$ hexapeptide. In addition, when the grain counts on the front and rear of cells were compared, there were statistically significant differences $(P<.002$, paired t-tests) seen at each concentration of peptide used.

In the studies described here, we examined spontaneously polarized cells, and these cells were studied using uniform fields (i.e., not gradients) of the chemoattractant f-Nle-Leu-Phe-Nle-Tyr-Lys. It might be argued that spontaneously polarized cells are unusual in some respect and may not represent the population of cells that are ordinarily stimulated by chemoattractants. These cells represented less than $4 \%$ of the entire PMN population, 

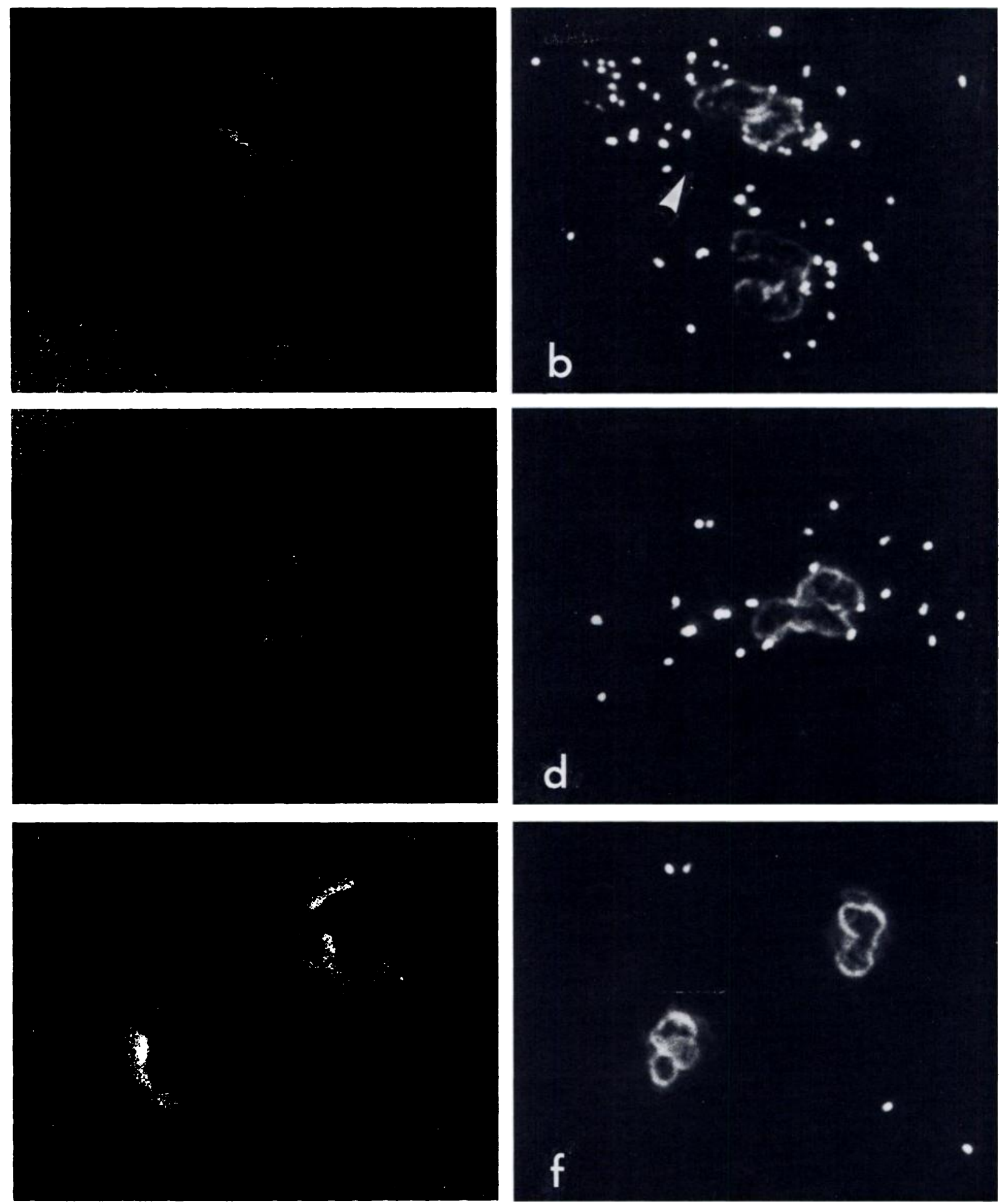

Fig. 6. Phase-contrast (left) and dark-field (right) microscopy showing spontaneously polarized human PMN (arrows). Cells were exposed to $\left({ }^{125} \mathrm{I}\right.$ )-labeled hexapeptide at $10 \mathrm{nM}(\mathrm{a}, \mathrm{b}), 5 \mathrm{nM}(\mathrm{c}, \mathrm{d})$, or at $10 \mathrm{nM}$ in the presence of $10 \mu \mathrm{M}$ unlabeled hexapeptide $(e, f)$. At both 5 and $10 \mathrm{nM}$ hexapeptide, silver grains appeared over the entire cell surface, with only a slight tendency toward the anterior of the cell. Cells exposed to labeled and excess unlabeled hexapeptide showed very fow cell-associated grains. Magnification bar $=10 \mu \mathrm{m}$. 

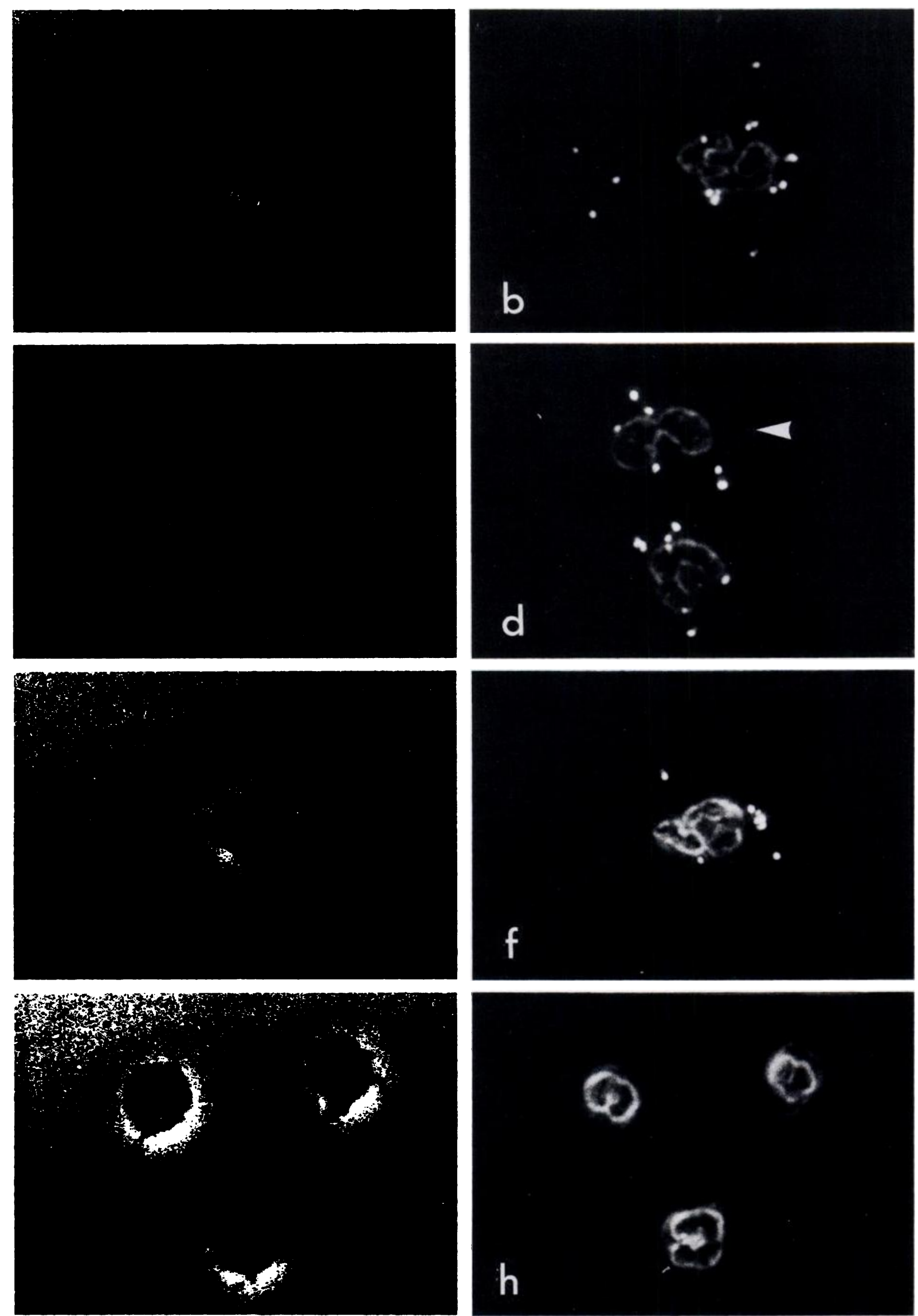

Figure 7 
TABLE 2. Hexapeptide Binding on Polarized Human PMN

\begin{tabular}{|c|c|c|c|c|}
\hline \multirow{2}{*}{$\begin{array}{l}\left({ }^{125} \mathrm{I}\right) \text {-hexapeptide } \\
\text { concentration }(\mathrm{nM}) \\
\left(15 \mathrm{~min} \text { at } 4^{\circ} \mathrm{C}\right)\end{array}$} & \multicolumn{2}{|c|}{ Grains/cells (mean \pm SEM) } & \multirow{2}{*}{$\begin{array}{c}\text { Ratio } \\
\text { (front/rear) }\end{array}$} & \multirow[b]{2}{*}{$\mathbf{P}^{b}$} \\
\hline & PMN front ${ }^{\mathrm{a}}$ & PMN rear ${ }^{a}$ & & \\
\hline 10 & $18.6 \pm 2.6$ & $13.2 \pm 3.7$ & 1.41 & - \\
\hline 5 & $17.2 \pm 2.3$ & $12.6 \pm 2.8$ & 1.37 & $>.20$ \\
\hline 2.5 & $13.4 \pm 1.4$ & $4.7 \pm 2.6$ & 2.86 & $<.001$ \\
\hline 1.25 & $8.1 \pm 0.8$ & $2.4 \pm 1.8$ & 3.33 & $<.001$ \\
\hline 0.63 & $4.8 \pm 1.2$ & $1.2 \pm 1.4$ & 4.00 & $<.001$ \\
\hline $\begin{array}{l}10 \mathrm{nM}+ \\
10 \mu \mathrm{M} \text { cold } \\
\text { hexapeptide }\end{array}$ & $0.2 \pm 0.1$ & $0.2 \pm 0.1$ & - & - \\
\hline
\end{tabular}

${ }^{\text {a }}$ Polarized PMN were transected with a line between the leading edge and trailing uropod tip. Grains over each half of the cell were then counted.

Three separate experiments were run; 50 cells were counted for each data point in each experiment.

When the number of grains at the front of each PMN was compared with that at the rear of each PMN using paired $t$ tests, values were found to be significantly different at the $P<.002$ for each concentration of labeled hexapeptide used.

bach ratio was compared to that calculated for $10 \mathrm{nM}$ hexapeptide binding concentration using Mann-Whitney U-test.

and the cause for their polarization or apparent motility is not known. The polarization of these cells might reflect previous stimulation by chemokinetic factors encountered during cell isolation or substrate adhesion. As a result, cell surface components such as the formylpeptide receptor might be redistributed over the cell surface in response to cell polarization. Similar secondary redistribution and resulting asymmetries of unoccupied receptors have been described previously for Fc and C3b receptors, and possible mechanisms for their occurrence have been discussed elsewhere [50,51].

On the other hand, these polarized cells may represent a small subpopulation of PMN that is particularly sensitive to chemokinetic or chemotactic stimuli. Increased sensitivity to chemokinetic activation might result from an unusually large or small number of receptors for chemoattractant or an unusual distribution of receptors on the cell surface. However, it appears that these spontaneously polarized cells are not unique with respect to their total hexapeptide binding. The total amount of hexapeptide bound to polarized cells was about the same as that bound to rounded cells in the general population at the same hexapeptide concentration (Table 3).

Fig. 7. Phase-contrast (left) and dark-field (right) autoradiographs of cells exposed to $\left({ }^{125} \mathrm{I}\right)$-hexapeptide. PMN were exposed to $2.5 \mathrm{nM}(\mathrm{a}, \mathrm{b}), 1.25 \mathrm{nM}(\mathrm{c}, \mathrm{d})$, or $0.63 \mathrm{nM}(e, \mathrm{f})$ lodinated hexapeptide, or to $2.5 \mathrm{nM}\left({ }^{125}\right)$-hexapeptide with a 1,000-fold excess of unlabeled hexapeptide $(\mathrm{g}, \mathrm{h})$. Polarized cells treated with $2.5 \mathrm{nM}$ labeled hexapeptide displayed many sllver grains over the anterior half of each cell. Polarized PMN exposed to either $1.25 \mathrm{nM}$ (arrow) or $0.63 \mathrm{nM}$ ( ${ }^{125}$ )-hexapeptide exhiblted fewer grains overall, but these grains were distributed predomInantly over the anterior half of each cell with very few grains seen over the uropod region. Magnification bar $=10 \mu \mathrm{m}$.

\section{DISCUSSION}

The results of our experiments using light microscope autoradiography to quantitate the amount of hexapeptide binding to human PMN are, in general, very similar to those obtained by conventional radioligand binding methods [23,28, Walter and Marasco, unpublished data]. However, while data from autoradiographic studies can be used to generate saturation-type curves for hexapeptide binding, it is much more useful for studying the formylpeptide binding characteristics of individual cells within the PMN population. Used in this way, certain aspects of this binding can be studied to great advantage.

\section{Cellular and Receptor Heterogenelty on Rounded PMN}

In the present study, all ligand-receptor interactions occurred at $4^{\circ} \mathrm{C}$, so that any active cellular responses to hexapeptide binding were greatly diminished or absent. As a result, inherent binding capacity is demonstrated such that binding is not a function of ongoing receptor clustering, membrane perturbation, endocytosis, or exocytosis. Under these conditions, there appear to be two basic mechanisms (Fig. 5) by which the observed differences in receptor binding may evolve. 1) Differences in receptor affinities: such differences might be attributed to either two entirely distinct receptors having different affinities (Fig. 5a) or to a single receptor exhibiting two different conformations (Fig. 5b). 2) Negative cooperativity among receptors: steric interference or other destabilizing interactions might occur among formylpeptide receptors under certain conditions. Increased inherent receptor clustering (cross-linking) (Fig. 5c) or certain membrane configurations (Fig. 5d) could cause poor accessibility of the peptide receptor or interference in hexapeptide binding to its receptor. 
TABLE 3. Hexapeptide Binding on Rounded and Polarized Human PMN

\begin{tabular}{lcc}
\hline \multirow{2}{*}{$\begin{array}{l}125 \\
\left.(15) \text { min at } 4^{\circ} \mathrm{C}\right)\end{array}$} & \multicolumn{2}{c}{ Grains/cell $(\text { mean } \pm \mathrm{SEM})^{\mathrm{a}}$} \\
\cline { 2 - 3 } & Rounded cells & Polarized cells \\
\hline 10 & $41.3 \pm 5.2$ & $31.8 \pm 6.7^{\mathrm{b}}$ \\
5 & $26.3 \pm 3.4$ & $29.8 \pm 4.6$ \\
2.5 & $18.8 \pm 2.8$ & $18.1 \pm 4.0$ \\
1.25 & $14.3 \pm 1.8$ & $10.5 \pm 2.4$ \\
0.63 & $7.8 \pm 1.0$ & $6.0 \pm 2.0$ \\
$10 \mathrm{nM}+10 \mu \mathrm{M}$ cold & $0.5 \pm 0.2$ & $0.4 \pm 0.2$ \\
$\quad$ hexapeptide & $0.6 \pm 0.3$ & $0.5 \pm 0.2$ \\
$2.5 \mathrm{nM}+2.5 \mu \mathrm{M}$ cold & & \\
$\quad$ hexapeptide & $0.6 \pm 0.2$ & $0.6 \pm 0.2$ \\
$\begin{array}{l}0.63 \mathrm{nM}+0.63 \mu \mathrm{M} \text { cold } \\
\text { hexapeptide }\end{array}$ & 0 \\
\hline
\end{tabular}

atal number of silver grains associated with 200 rounded cells or 50 polarized cells were counted. Three separate experiments were run.

b The mean grain counts calculated for rounded and polarized cells at each hexapeptide concentration were compared using chi-square. Values at each concentration were not significantly different.
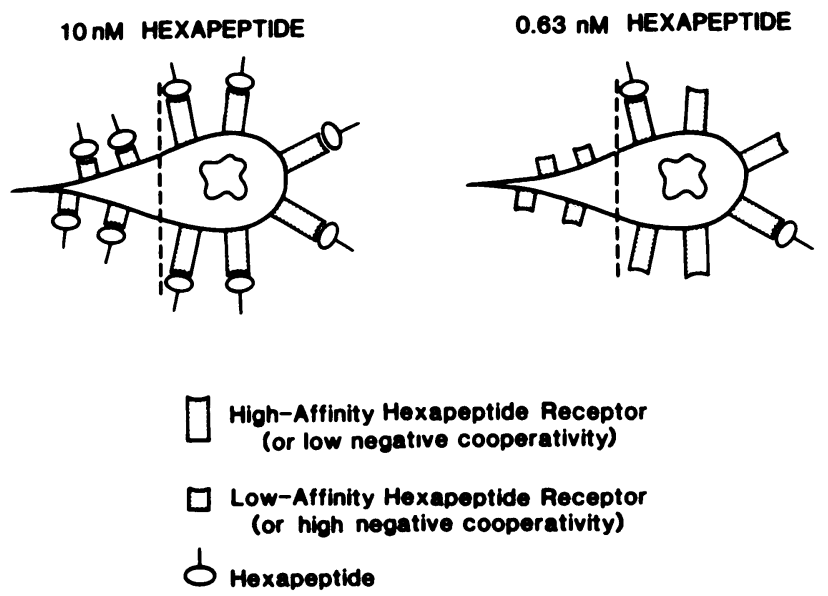

Fig. 8. Diagram representing formylhoxapeptide receptor distribution and hexapeptide binding on spontaneously polarized PMN. High-affinity or low negative cooperativity receptors are distributed primarily over the anterior half of the polarized cell. Low-affinity/high negative cooperativity receptors may be distributed more uniformly or only on the posterior half of the cell. Thus, at high concentrations of hexapeptide (> $2.5 \mathrm{nM}$ ), much hexapeptide would bind to both the anterior and posterior halves of the PMN. As the concentration of free chemoattractant decreased, the amount of hexapeptide binding to the lowaffinity/high negative cooperativity receptors on the posterior half of the cell would decrease rapidly, while the amount of hexapeptide binding to the receptors on the anterior half of the cell would decrease at a comparatively low rate. As a result, hexapeptide would bind asymmetrically over the PMN cell surface with an increasing proportion on the anterior half of the cell.
The occurrence of receptor heterogeneity (high- and low-affinity binding states or differences in negative cooperative interactions) for the formylpeptide chemotaxis receptor may result from the interaction of the cytoskeleton with the cell surface (see Fig. 5b). Such interactions might cause the expression of the high-affinity receptor state, whereas receptors not interacting with the cytoskeleton might remain as low-affinity binding sites for hexapeptide. Jesaitis et al [15] have described the formation of high-affinity formylpeptide receptor complexes associated with detergent-insoluble "cytoskeletons" of human granulocytes. White et al [54] have shown that actin becomes associated with such "cytoskeletons" after cells are stimulated with formylpeptide. However, at present, no direct or indirect linkages between the cytoskeleton and surface formylpeptide receptors have been demonstrated.

Populations of PMN are also known to exhibit heterogeneity in their rates of locomotion [12], immunoglobulin G Fc receptor expression and Fc receptor-mediated activity $[16,56]$, membrane potential responsiveness to formylpeptide [35], cell density [30], and cell surface antigens $[3,37]$. The observed variability or heterogeneity in the numbers of receptors expressed by PMN within the sample population may then have functional significance. Certain subpopulations of PMN may be more effective in detecting or transducing chemotactic stimuli as a result of the cellular or receptor heterogeneity of chemotaxis receptors on the cell surface. Consequently, some PMN may respond to formylpeptide at lower concentrations than do other PMN, and this subpopulation of cells may also exhibit lower thresholds for chemotactic deactivation or for degranulation.

\section{Receptor Heterogeneity on Polarized PMN}

The distribution of hexapeptide bound to polarized cells differed, depending on the concentration of hexapeptide to which the cells were exposed during binding. At high concentrations, hexapeptide bound to receptors across the entire cell surface, although with some apparent tendency toward the anterior half of the cell. However, at lower concentrations, hexapeptide bound primarily to receptors lying on the anterior half of the cell. These data suggest that high- and low-affinity hexapeptide receptors may be expressed asymmetrically on the surface of spontaneously polarized PMN (see Fig. 8). High-affinity formylhexapeptide receptors evidently lie predominantly over the anterior half of polarized cells and low-affinity receptors mainly over the rear or posterior half of each PMN. Thus at lower hexapeptide concentrations $(<5 \mathrm{nM})$, hexapeptide would bind preferentially to the front of polarized PMN, whereas at high hexapeptide concentrations ( $\geqslant 5 \mathrm{nM}$ ) hexapeptide would bind somewhat more uniformly over the cell surface. 
Studies by Snyderman and co-workers $[17,40,57]$ indicated that the leukocyte formylpeptide receptor may exist in two partially interconvertible affinity states. The high-affinity state enhances chemotaxis and depresses lysosomal enzyme secretion, whereas the low-affinity state depresses chemotaxis and enhances enzyme secretion. The existence of two such receptor states is entirely consistent with the data presented here. The conversion between these two affinity states is apparently regulated by guanine nucleotides [18] and by agents that alter membrane fluidity [57]. Fluctuations in local calcium and cyclic nucleotide levels are also known to occur in PMN stimulated by chemoattractants [7,39]. Global or local alterations such as this may affect the affinity of nearby formylpeptide receptors, inducing the asymmetric distribution of high-affinity receptors described here.

The asymmetric distribution of hexapeptide receptors described here might aid in directed locomotion by amplifying differential transcellular binding occurring in formylpeptide concentration gradients [11,31]. It may promote random or perpetuate directed locomotion by restricting binding of chemotactic stimuli to a particular region of the cell surface. This might create apparent gradients across the cell surface, even without actual chemical diffusion gradients. In either case, local activation of the motile apparatus might occur in regions of increased chemoattractant binding. Formylpeptide binding to leukocytes is known to induce changes in actin conformation [49] and in the occurrence and distribution of microtubules $[20,44]$. In addition, several cytoskeletal proteins have been shown to be asymmetrically distributed in polarized leukocytes $[20,29,43,48]$. Such asymmetric activation of the cytoskeleton probably functions in initiating or imparting directionality to cell locomotion.

These data may also help reconcile differences between our published data [52] and that of Sullivan et al [47] regarding formylpeptide receptor distributions on the surface of PMN. Although both of these studies employed rabbit peritoneal PMN, substantially different experimental procedures were employed, and the results seemed somewhat contradictory. However, we used nearly saturating concentrations of hexapeptide in our initial study, resulting in almost uniform distributions of hexapeptide over the cell surface. The formylpeptide concentration used by Sullivan et al was not stated but may well have been subsaturating. Assuming that rabbit PMN display heterogeneity in binding formylpeptide similar to that shown here for human PMN, Sullivan et al may have observed only the binding of high-affinity receptors over the anterior half of each cell. The remaining low-affinity receptors would not be seen at subsaturating formylpeptide concentrations.

The data presented here may also help explain why high concentrations of chemotactic factor tend to reduce rather than stimulate directed locomotion [28,33]. At high concentrations, formylpeptide would bind to highand low-affinity receptors over the entire cell surface, such that PMN could not sense or respond appropriately to a gradient of chemoattractant. At lower concentrations, a certain proportion of the high-affinity receptors would be occupied and the low-affinity receptors largely unoccupied. Since the high-affinity receptors (at least) are distributed asymmetrically over the cell, they may promote the sensing of hexapeptide concentration gradients and the subsequent locomotory response. This apparent asymmetry in hexapeptide receptor binding may be unique to spontaneously polarized PMN. However, it seems probable that similar asymmetries will be found in cells stimulated by specific chemokinetic agents or cells oriented in chemotactic gradients. We are currently investigating these possibilities.

In this study, we have shown that rounded human PMN exhibit both receptor and cellular heterogeneity with respect to the formylpeptide receptor and that spontaneously polarized PMN display asymmetric arrays of these receptors across their cell surfaces. The resulting asymmetric binding of hexapeptide might stimulate cell polarization and locomotion by amplifying differences in concentration gradients across the cell surface. Such asymmetries might then promote random locomotion or perpetuate directed locomotion by providing preferred sites for chemotactic factor binding and, consequently, local activation of the motile apparatus.

\section{ACKNOWLEDGMENTS}

The authors would like to thank The University of Illinois Blood Bank for their assistance in obtaining blood samples, M. Patel for his advice regarding the statistical analyses performed here, and Doug Feltner for stimulating discussions. This study was supported in part by grant No. 85-26 from the American Cancer Society, Illinois Division, Inc. (R.J.W.) and by NIH grants No. 28445-05 and No. 33003-02 (W.A.M.).

\section{REFERENCES}

1. Adler, J. Chemoreceptors in bacteria. Science 166, 1588, 1969.

2. Aswanikumar, S., Corcoran, B., Schiffman, E., Day, A.R., Freer, R.J., Showell, H.J., and Pert, C.B. Demonstration of a receptor on rabbit neutrophils for chemotactic peptides. Biochem. Biophys. Res. Commun. 74,810, 1977.

3. Ball, E.D., Graziano, R.F., Shen, L., and Fanger, M.W. Monoclonal antibodies to novel myeloid antigens reveal human neutrophil heterogeneity. Proc. Natl. Acad. Sci. U.S.A. 79,5374, 1982.

4. Becker, E.L., and Marasco, W.A. Chemotaxis and activation of neutrophils. In Symposium on Chemical Mediators of Inflammation (Cohen, S., Hayashi, H., Saito, K., and Takado, A., Eds.) New York, Academic Press, 1985.

5. Fertuck, H.C., and Salpeter, M.M. Sensitivity in electron microscope autoradiography for I-125. J. Histochem. Cytochem. 22,80, 1974.

6. Gallin, J.I. Human neutrophil heterogeneity exists, but is it meaningful? Blood 63,977, 1984. 
7. Gallin, J.I., and Rosenthal, A.S. The regulatory role of divalent cations in human granulocyte chemotaxis: Evidence for an association between calcium exchanges and microtubule assembly. J. Cell Biol. 62,594, 1974.

8. Gallin, J.I., Seligmann, B.E., and Fletcher, M.P. Dynamics of human neutrophil receptors for the chemoattractant fmet-leu-phe. Agents Actions (Suppl.) 12,290, 1983.

9. Goldman, D.W., and Goetzl, E.J. Heterogeneity of human polymorphonuclear leukocyte receptors for leukotriene B4: Identification of a subset of high affinity receptors that transduce the chemotactic response. J. Exp. Med. 159, 1027, 1984.

10. Harvath, L., and Leonard, E.J. Two neutrophil populations in human blood with different chemotactic activities: Separation and chemoattractant binding. Infect. Immun. 36,443, 1982.

11. Hewitt, J.A. Diffusion gradients, membrane receptors, and the acquisition of orientational information by cells. J. Theor. Biol. 74,297, 1978.

12. Howard, T.H. Quantification of the locomotive behavior of polymorphonuclear leukocytes in clot preparations. Blood 59,946, 1982.

13. Jesaitis, A.J., Naemura, J.R., Painter, R.G., Schmitt, M., Sklar, L.A., and Cochrane, C.G. The fate of the $\mathrm{N}$-formyl-chemotactic peptide receptor in stimulated human granulocytes: Subcellular fractionation studies. J. Cell. Biochem. 20,177, 1982.

14. Jesaitis, A.J., Naemura, J.R., Painter, R.G., Sklar, L.A., and Cochrane, C.G. The fate of an $\mathrm{N}$-formylated chemotactic peptide in stimulated human granulocytes: Subcellular fractionation studies. J. Biol. Chem. 258, 1968, 1983.

15. Jesaitis, A.J., Naemura, J.R., Sklar, L.A., Cochrane, C.G., and Painter, R.G. Rapid modulation of $\mathbf{N}$-formyl chemotactic peptide receptors on the surface of human granulocytes: Formation of high-affinity ligand-receptor complexes in transient association with cytoskeleton. J. Cell Biol. 98,1378, 1984.

16. Klempner, M.S., and Gallin, J.I. Separation and functional characterization of human neutrophil subpopulations. Blood 51,659, 1980.

17. Koo, C., Lefkowitz, R.J., and Snyderman, R. The oligopeptide chemotactic factor receptor on human polymorphonuclear leukocyte membranes exists in two affinity states. Biochem. Biophys. Res. Commun. 106,442, 1982.

18. Koo, C., Lefkowitz, R.J., and Snyderman, R. Guanine nucleotides modulate the binding affinity of the oligopeptide chemoattractant receptor on human polymorphonuclear leukocytes. J. Clin. Invest. 72,748, 1983.

19. Mackin, W.M., Huang, C.-K., and Becker, E.L. The formylpeptide chemotactic receptor on rabbit peritoneal neutrophils. I. Evidence for two binding sites with different affinities. J. Immunol. $129,1608,1982$.

20. Malech, H.L., Root, R.K., and Gallin, J.I. Structural analysis of human neutrophil migration: Centriole, microtubule, and microfilament orientation and function during chemotaxis. J. Cell Biol. 75,666, 1977.

21. Marasco, W.A., Phan, S.H., Krutzsch, H., Showell, H.J., Feltner, D.E., Nairn, R., Becker, E.L., and Ward, P.A. Purification and identification of formyl-methionyl-leucyl-phenylalanine as the major peptide neutrophil chemotactic factor produced by Escherichia coli. J. Biol. Chem. 259,5430, 1984.

22. Marasco, W.A., Becker, K.A., Feltner, D.E., Brown, C.S., Ward, P.A., and Nairn, R. Covalent affinity labeling, detergent solubilization, and fluid-phase characterization of the rabbit neutrophil formyl peptide chemotaxis receptor. Biochem. 24,2227, 1985.

23. Marasco, W.A., Feltner, D.E., and Ward, P.A. Formyl peptide chemotaxis receptors on the rat neutrophil: Experimental evidence for negative cooperativity. J. Cell.Biochem. 27,359, 1985.
24. Miyake, Y., Tadashi, Y., Kazuhiro, F., Suginaka, H., Nakajima, T., and Moriyama, T. Purification and characterization of neutrophil chemotactic factors of Streptococcus sanguis. Biochim. Biophys. Acta 758,181, 1983.

25. Mannervik, B. Regression analysis, experimental error, and statistical criteria in the design and analysis of experiments for discrimination between rival kinetic models. Methods Enzymol. 87,370, 1982.

26. Munson, P.J., and Rodbard, D. Ligand: A versatile computerized approach for characterization of ligand-binding systems. Anal. Biochem. 107,220, 1980.

27. Niedel, J.E., and Cuatrecasas, P. Formyl peptide chemotactic receptors of leukocytes and macrophages. Curr. Top. Cell. Regul. 17,137, 1980.

28. Niedel, J., Wilkinson, S., and Cuatracasas, P. Receptor-mediated uptake of I-125-chemotactic peptide by human neutrophils. J. Biol. Chem. 254, 10700, 1979.

29. Oliver, J.M., Krawiec, J.A., and Becker, E.L. The distribution of actin during chemotaxis in rabbit neutrophils. J. Reticuloendothel. Soc. 24,697, 1978.

30. Pember, S.O., Barnes, K.C., Brandt, S.J., and Kinkade, J.M. Density heterogeneity of neutrophilic polymorphonuclear leukocytes: Gradient fractionation and relationship to chemotactic stimulation. Blood 61,1105, 1983.

31. Ramsey, W.S. Retraction fibers and leucocyte chemotaxis. Exp. Cell Res. 86,184, 1974.

32. Salpeter, M.M., Fertuck, H.C. and Salpeter, E.E. Resolution in electron microscope autoradiography. III. Iodine-125, the effect of heavy metal staining, and a reassessment of critical parameters. J. Cell Biol. 72,161, 1977.

33. Schiffman, E., Corcoran, B.A., and Wahl, S.M. N-formylmethionyl peptides as chemoattractants for leukocytes. Proc. Natl. Acad. Sci. U.S.A. 72,1059, 1975.

34. Schiffman, E., and Gallin, J.I. Biochemistry of phagocyte chemotaxis. Curr. Top. Cell. Regul. 15,203, 1979.

35. Seligmann, B., Chused, T.M., and Gallin, J.I. Differential binding of chemoattractant peptide to subpopulations of human neutrophils. J. Immunol. 133, 2641, 1984.

36. Seligmann, B.E., Fletcher, M.P., and Gallin, J.I. Adaptation of human neutrophil responsiveness to the chemoattractant $\mathrm{N}$ formylmethionylleucylphenylalanine: Heterogeneity and/or negative cooperative interaction of receptors. J. Biol. Chem. 257,6280, 1982.

37. Seligmann, B.E., Malech, H.L., Melnick, D.A. and Gallin, J.I., An antibody binding to human neutrophils demonstrates antigenic heterogeneity detected early in myeloid maturation which correlates with functional heterogeneity of mature neutrophils. J. Immunol. 135, 2647, 1985.

38. Shields, J.M., and Haston, W.S. Behaviour of neutrophil leucocytes in uniform concentrations of chemotactic factors: Contraction waves, cell polarity, and persistence. J. Cell Sci. 74,75, 1985.

39. Smolen, J.E., Korchak, H.M., and Weissman, G. Increased levels of cyclic adenosine-3',5' monophosphate in human polymorphonuclear leukocytes after surface stimulation. J. Clin. Invest. $65,1077,1980$.

40. Snyderman, $R$. Chemoattractant receptor affinity reflects its ability to transduce different biological responses. In Leukocyte Locomotion and Chemotaxis (Keller, H.U., and Till, G.O., eds.) Basel, Birkhauser Verlag, p. 323, 1983.

41. Snyderman, R., and Pike, M.C. Chemoattractant receptors on phagocytic cells. Annu. Rev. Immunol. 2,257, 1984.

42. Snyderman, R., and Pike, M.C. Transcuctional mechanisms of chemoattractant receptors on leukocytes. Contemp. Top. Immunobiol. 14,1, 1984. 
43. Southwick, F.S., and Stossel, T.P. Contractile proteins in leukocyte function. Semin. Hematol. 20,305, 1983.

44. Spilberg, I., Mandell, B., and Hoffstein, S. A proposed model for chemotactic deactivation: Evidence for microtubule modulation of polymorphonuclear leukocyte chemotaxis. J. Lab. Clin. Med. 94,361, 1979.

45. Stossel, T.P., Hartwig, J.H., Yin, H.L., Southwick, F.S., and Zaner, K.S. The motor of leukocytes. Fed. Proc. 43,2760, 1984.

46. Sullivan, J.A., and Mandell, G.L. Motility of human polymorphonuclear neutrophils: Microscopic analysis of substrate adhesion and distribution of F-actin. Cell Motil. 3,31, 1983.

47. Sullivan, S.J., Daukas, G., and Zigmond, S.H. Asymmetric distribution of the chemotactic peptide receptor on polymorphonuclear leukocytes. J. Cell Biol. 99,1461, 1984.

48. Valerius, N.H., Stendahl, O., Hartwig, J.H., and Stossel, T.P. Distribution of actin-binding protein and myosin in polymorphonuclear leukocytes during locomotion and phagocytosis. Cell 24,196, 1981.

49. Wallace, P.J., Wersto, R.P., Packman, C.H., and Lichtman, M.A. Chemotactic peptide-induced changes in neutrophil actin conformation. J. Cell Biol. 99,1060, 1984.

50. Walter, R.J., Berlin, R.D., and Oliver, J.M. Asymmetric Fc receptor distribution on human PMN oriented in a chemotactic gradient. Nature 286,724, 1980.
51. Walter, R.J., Berlin, R.D., Pfeiffer, J.R., and Oliver, J.M. Polarization of endocytosis and receptor topography on cultured macrophages. J. Cell Biol. 86,199, 1980.

52. Walter, R.J., and Marasco, W.A. Localization of chemotactic peptide receptors on rabbit neutrophils. Exp. Cell Res. 154,163, 1984.

53. Weinbaum, D.L., Sullivan, J.A., and Mandell, G.L. Receptors for concanavalin A cluster at the front of polarized neutrophils. Nature 286,725, 1980.

54. White, J.R., Naccache, P.H., and Sha'afi, R.I. Stimulation by chemotactic factor of actin association with the cytoskeleton in rabbit neutrophils: Effects of calcium and cytochalasin B. J. Biol. Chem. 258, 14041, 1983.

55. Williams, L.T., Snyderman, R., Pike, M.C., and Lefkowitz, R.J. Specific receptor sites for chemotactic peptides on human polymorphonuclear leukocytes. Proc. Natl. Acad. Sci. U.S.A. 74,1204, 1977.

56. Wong, L., and Wilson, J.D. The identification of Fc and C3b receptors on human neutrophils. J. Immunol. Methods 7,69, 1975.

57. Yuli, I., Tomonaga, A., and Snyderman, R. Chemoattractant receptor functions in human polymorphonuclear leukocytes are divergently altered by membrane fluidizers. Proc. Natl. Acad. Sci. U.S.A. 79,5906, 1982. 